\title{
PENGARUH FLIPBOOK GERBANG LOGIKA DENGAN MENGGUNAKAN LIVEWIRE TERHADAP KEMAMPUAN BERPIKIR LOGIS MAHASISWA TEKNIK INFORMATIKA
}

\author{
Rizki Noor Prasetyono, Rito Cipta Sigitta H. \\ Fakultas Sains dan Teknologi, Universitas Peradaban Bumiayu, Indonesia \\ pr45t91@gmail.com
}

Diterima: Nopember 2019. Disetujui: Desember 2019. Dipublikasikan: Desember 2019

\begin{abstract}
ABSTRAK
Penelitian ini bertujuan untuk menjelaskan bagaimana pengaruh penggunaan flipbook gerbang logika dengan menggunakan livewire terhadap kemampuan berpikir logis mahasiswa. Subjek penelitian yaitu mahasiswa teknik informatika yang sedang menempuh mata kuliah rangkaian digital semester 6 tahun 2018/2019. Desain penelitian berupa pre-experimental design dengan jenis one group pretest-posttest. Dari hasil data regresi sederhana dengan menggunakan SPSS yaitu didapatkan $\mathrm{p}$ Value Sig. $0,000<0,05$ yang berarti penggunaan flipbook gerbang logika menggunakan livewire berpengaruh pada kemampuan berpikir logis mahasiswa teknik informatika. Presentase 64,5\% kemampuan berpikir logis dipengaruhi oleh penggunaan flipbook materi gerbang logika bantuan livewire. Persamaan regresi sederhana sebagai berikut $\widehat{\boldsymbol{Y}}=-\mathbf{8 1 , 7 7 6}+$ 18, 503 $x$ memiliki arti flipbook materi gerbang logika bantuan livewire memiliki pengaruh positif terhadap kemampuan berpikir logis mahasiswa.

Kata kunci: Flipbook, Gerbang Logika, livewire, kemampuan berpikir logis
\end{abstract}

\begin{abstract}
The purpose of the research to explain how the effect of the use of logic gates flipbook using livewire against logical thinking ability of students. The research subjects were informatics engineering students who took digital circuit courses in semester 6 of 2018/2019. The research design was pre-experimental design with one group pretest-posttest type. From the results of simple regression data using SPSS that is obtained $p$ Value Sig. 0,000<0,05, which means that the use of flipbook logic gates using livewire has an effect on the ability to think logically in informatics engineering students. The percentage $64.5 \%$ of logical thinking ability is influenced by the use of flipbook material for livewire logic gate assistance. The simple regression equation as follows $Y=-81,776+18,503 x$, that's means the flipbook using livewire in logical gate material has a positive influence on students' logical thinking abilities.
\end{abstract}

Keywords: Flipbook, Logic Gate, livewire, logical thinking skills

\section{PENDAHULUAN}

Inovasi pembelajaran dalam pendidikan tinggi atau tingkat universitas diperlukan mengingat perkembangan teknologi yang semakin canggih. Dengan adanya teknologi yang bisa memberikan bantuan dalam pelaksanaan pembelajaran. Permenristekdikti No.32/2016, yang berisi bahwa BAN PT harus mengembangkan instrument akreditasi yaitu yang sekarang
IAPS 4.0 yang merujuk pada output/ outcome. Dimana ini menjadi tuntutan juga untuk tenaga pendidik dalam hal ini dosen untuk menyusun program pembelajaran yang berbasis output/ outcome.

Media dalam belajar sangat membantu dalam pembelajaran. Apabila media yang diberikan output/ outcome yang dihasilkan setelah mempelajari media 
tersebut bermanfaat, khususnya untuk pembelajaran dipendidikan tinggi. Mahasiswa yang menempuh kuliah tidak selamanya mendapatkan ilmu dari perkuliahan akan tetapi diluar perkuliahan. Untuk memberikan arahan diluar perkuliahan dosen bisa memberikan media ini sebagai tambahan untuk mendapatkan ilmu.

Media interaktif dengan teknologi yang sekarang menjadi multimedia interaktif. Multimedia interaktif terdiri dari dua kata yaitu multimedia yang merujuk pada kumpulan terstruktur berupa materi/teks, gambar, video, suara atau animasi (Philips, 2014). Interaktif yaitu mengacu pada penggunaan komputer untuk melakukan pemrosesan atau melakukan aksi atau kegiatan dengan komputer. Menurut Phillips juga multimedia yang interaktif itu harus menggunakan komputer dalam penerapanya, apanila tidak itu tidak bisa disebut multimedia interaktif. Multimedia interaktif dalam hal ini bisa buku interaktif bisa membantu memberikan dampak luaran mahasiswa dalam perkuliahan. Penelitian Dünser dkk (Dünser, Walker, Horner, \& Bentall, 2012) dengan membut buku fisika interaktif dengan bantuan augmented reality $(A R)$ yang memberikan efektifitas dalam pembelajaran. Buku tersebut juga memberikan hasil luaran untuk pembacanya yaitu menambah pemahaman materi yang abstrak dengan bantuan AR untuk menampilkan gambar yang bisa diinteraksikan.

Keunggulan buku interaktif memberikan kebebsan mahasiswa belajar didalam maupun diluar perkuliahan. Dengan bantuan interaksi secara lansung menambah pehamaham mahasiswa untuk teori yang bersifat abstrak. Kemudian interaksi ini juga bisa menambah kreatifitas mahasiswa untuk membuat projek maupun materi pengembangan dari materi utama. Hal ini juga didukung dalam buku interaktif dengan
AR siswa bisa dengan mudah mengingat karena teori yang dijelasakan teraplikasi oleh AR dengan tampilan visual sehingga bisa menambah pemahaman konsep (Dünser et al., 2012).

Buku interaktif yang diintegrasikan dengan teknologi menjadi tuntutan untuk era digital 4.0. Menerapkan prinsip paperless yaitu pengurangan penggunaan kertas untuk mendukung kampanye lingkungan juga. Ebook atau Electronic book buku yang berbasis perangkat lunak untuk membacanya sangat efektif untuk digunakan. Penelitian Rockinson mengenai buku tradisional yaitu buku dalam berbasis kertas dengan buku elektronik, menujukan nilai signifikansi lebih tinggi dari pembelajaran menggunakan buku elektronik (Rockinson- Szapkiw, Courduff, Carter, \& Bennett, 2013). Didukung dalam penelitian Diah \& Rudi menujukan bahwa penggunaan buku elektronik yang interaktif efektif dalam melatih siswa kemempuan berpikir tingkat tinggi (High Order Thinking Skills) (Diah \& Rudy, 2017). Dan respon siswa yang baik mengenai buku elektronik interaktif dilihat dari operasi yang mudah, tampilan yang menarik, materi yang mudah dipahami, bisa dilakukan interaksi, motivasi dalam pembelajaran, dan melatih dalam kemampuan berpikir tingkat tinggi.

Materi gerbang logika merupakan bagian dari rangkaian digital berisi pengenalan digital. Mahasiswa harus mengunakan pola pikir yang berbeda untuk masuk dalam materi gerbang logika. Karena operasi dalam gerbang logika memerlukan pemahaman dan latihan. Sebagai contoh untuk operasi gerbang OR sebagai berikut $\boldsymbol{A}+\boldsymbol{B}=\boldsymbol{X}$, dimana $\mathrm{A}$ dan $\mathrm{B}$ menyatakan untuk input gerbang tanda + merupakan operasi gerbang OR dan X adalah ouput. Sistem digital menggunakan bilangan binner yaitu 0 dan 1. Apabila masukan A dan B bernilai 1 maka bagaimana nilai output $X$ untuk operasi gerbang OR. Jika dengan 
aljabar biasa maka hasil untuk operasi $\mathbf{1}+$ $\mathbf{1}=\mathbf{2}$ hasil ini sudah terekam diotak. Sedangkan untuk operasi gerbang OR tidak menggunakan aljabar biasa yaitu menggunakan aljabar booelan yang menggunakan angka biner 0 dan 1 , artinya $\mathbf{1}+\mathbf{1}=\mathbf{1}$. Karena dalam bilangan biner 1 merpresantasikan bilangan high (tinggi) jadi semua angka yang bernilai diatas satu masuk kedalam bilangan ini. Untuk bilangan biner 0 merepresantasikan angka yang lebih kecil dari satu. Hal ini membutuhkan kemampuan logis yang lebih baik lagi karena menambah pemahaman aljabar baru.

Observasi yang didapatkan dari wawancara sederhana sebagian mahasiswa dalam belajar melakukan kegiatan menghafal dan menunjukan bahwa mereka hanya mengulang jawaban yang mereka hafalkan tanpa melalui proses berpikir. Menurut Mukhayat dalam (Nursuprianah \& Fitriyah, 2012) dengan metode menghafal dalam belajar hanya mengulang apa yang dipelajari tidak melalui proses berpikir secara kompleks. Untuk menghilangkan kebiasaan menghafal mahasiswa harus melalui berbagai cara. Salah satunya melalui kegiatan praktikum yang bisa membangun pemahaman secara konkret. Subekti juga dalam penelitiannya menyebutkan bahwa untuk mengubah kebiasaan menghafal dalam belajar melalui pembelajaran berbasis mahasiswa aktif dengan paradigma proses pembelajaran pengalaman pribadi, membangun mapun menemukan kembali konsep-konsep, abstraksi, dan aplikatifnya (Subekti, 2011). Sedangkan dalam mata kuliah gerbang logika yang didalamnya memuat materi aljabar booelan harus memiliki pemahaman dalam operasi bilangan biner. Menurut teori Piaget mengenai perkembangan kognitif anak bisa disimpulkan bahwa, mahasiswa merupakan pada tahapan kemampuan pemahaman yang abstrak dan berpikir logis dengan hipotesis deduktif dan induktif (Hanfstingl, Benke, \& Zhang, 2019).

Berpikir logis untuk tingkatan mahasiswa untuk membuat mereka mampu mengubah pola pikir untuk relatif dalam segala perspektif. Seperti pada halnya untuk menyelesaikan permasalahan aljabar biasa dengan aljabar bilangan biner harus bisa membedakan proses operasinya.

Pembangunan berpikir logis secara induktif lebih mampu untuk diterapkan dalam materi gerbang logika. Karena proses berpikir ini melalui pengalaman secara lansung melalui kegiatan praktikum, pemecahan masalah, dan kenyataan atau realistik. Melalui metode ini mahasiswa mengalami secara langsung melalui indra mereka bahwa kenyataan dengan materi yang sudah ada ternyata benar dan bisa membuat kesimpulan secara langsung. Untuk mempunculkan kemampuan beralasan logis melalu pengalaman secara langsung dan realistik membuat kemampuan berpikir logis siswa lebih baik (Bird, 2010). Dalam Fediana dkk juga menyebutkan bahwa untuk proses dalam mendekatkan untuk berpikir logis yaitu bisa melibatkan dalam memperoleh, menganalisis, dan menguji formulasi hipotesis ketika peroses pembelajaran (Fadiana, Amin, Lukito, Wardhono, \& Aishah, 2019)

Penelitian yang relevan seperti pada penelitian Divayana dkk pembuatan flipbook menarik siswa ketika membaca dan memudahkan siswa dalam mendapatkan pengetahuan. (Divayana, Suyasa, Ariawan, Mahendra, \& Sugiharni, 2019). Priwantoro dkk dalam penelitianya juga dalam pengembangan dan penggunaan flipbook dari hasil validasi ahli dikategorikan baik (Priwantoro, Fahmi, \& Astuti, 2018). Penelitian Hidayatulloh juga mengembangkan mengenai flipbook menujukan bahwa validitasnya layak, 
kemudian kategorinya sangat praktis dan efektif (Hidayatulloh, 2019). Pengembangan bahan ajar berbasis flipbook mendapatkan validitas, kepraktisan dan efektivitas yang layak digunakan dalam pembelajaran (Andini, Fitriana, \& Budiyono, 2018; Wibowo \& Dkk, 2018). Dari beberapa penelitian tersebut menunjukan bahwa pentingnya pengembangan media pembelajaran yang berkaitan dengan teknologi untuk perkembangan pendidikan.

Pentingnya mahasiswa dalam berpikir logis untuk materi gerbang logika, menjadikan suatu kebutuhan untuk membuat mahasiswa mengubah pola pikir mereka. Mengubah pemikiran abstraksi mereka dalam penyelesaian masalah dan pemahaman materi dibutuhkan bantuan pengalaman melalui kegiatan interaktif mahasiswa secara lansung. Penelitian Riyanti dkk melalui pembelajaran yang melibatkan dalam mengamati, membandingkan, bertanya, dan memproses informasi data secara langsung dapat mengembangkan kemampuan berpikir logis (Riyanti, Karyanto, \& Article, 2018). Dalam penelitian Andriani dkk menyatakan melalui kegiatan pembelajaran aktif siswa yaitu inkuiri yang tebimbing mampu meningkatkan pemikiran siswa dalam berpikir logis (Andriani, Nurlaelah, \& Yulianti, 2019).

Dari uraian diatas dapat diungkapkan permasalahan yang muncul adalah untuk mengetaui pengaruh pembelajaran menggunakan Flipbook materi gerbang logika dengan berbantuan livewire yang digunakan mahasiswa untuk interaktif dalam pengalaman belajar dalam berpikir logis.

\section{METODE PENELITIAN}

\section{Jenis Penelitian}

Penelitian ini merupakan penelitian pre-experimental design dengan jenis one group pretest-posttest sesuai dengan tabel 1.
Untuk mengetahui dan menjelaskan pengaruh antara variabel terikat kemampuan berpikir logis dan variabel bebas Flipbook gerbang logika dengan berbantuan livewire.

Tabel 1. Desain Penelitian

\begin{tabular}{lccc}
\hline \multicolumn{1}{c}{ Kelompok } & Pretest & Perlakuan & Posttest \\
\hline $\begin{array}{l}\text { Kelas } \\
\text { eksperimen }\end{array}$ & $O_{1}$ & $X$ & $O_{2}$ \\
\hline Keterangan : & & \\
$O_{1}$ & : & Pretes pada kelas eksperimen \\
$O_{2}$ & : Postes pada kelas eksperimen \\
$X$ & : Penggunaan Flipbook Gerbang \\
& \multicolumn{2}{l}{ Logika dengan Livewire } \\
\hline
\end{tabular}

\section{Subjek Penelitian}

Populasi untuk penetian adalah mahasiswa semester 6 (genap) dengan jumlah total 30 mahasiswa ataupun satu angkatan/satu kelas. Teknik pengambilan sampel yang digunakan adalah "sampel jenuh" artinya seluruh populasi yang sudah ditentukan digunakan sebagai sampel penelitian. Hal ini dikarenakan jumlah populasi mahasiswa semester 6 relatif lebih kecil.

\section{Prosedur}

Tahap awal ini menganilisis kebutuhan untuk pembelajaran rangkaian digital pada materi gerbang logika. Dimana untuk mengembangkan kemampuan berpikir logis dari mahasiswa dalam materi gerbang logika. Pemilihan sampel sesuai dengan materi yang ditempuh pada mahasiswa teknik informatika semester genap. Kemudian menganalisis uji prasyarat dengan mengambil data pretes kemudian diuji validitas dan homogenitas. Menyusun tahapan pembelajaran sesuai dengan bahan ajar yang digunakan, menyusun instrument dan menganalisis intrumen tes tersebut. Mempersiapkan Flipbook gerbang logika 
dengan menggunakan Livewire untuk pembelajaran.

Tahap Penelitian dilakukan penerapan penggunaan Flipbook gerbang logika dengan menggunakan Livewire. Tahapan ini dilakukan empat kali pertemuan untuk membahas konsep dasar digital, gerbang logika dasar, dan gerbang logika campuran/ kombinasi. Dengan Melakukan tahap pembelajaran melalui penggunaan flipbook materi gerbang logika yang dalam prosesnya mahasiswa mencoba dan berinovasi dengan praktikum untuk menumbuhkan kemampuan berpikir logis.

Pada tahap akhir dilakukan menyusun pengambilan data penelitian dengan pengambilan postes setelah dilakukan perlakuan. Kemudian menganalisis data pretes dan postes yang sudah dilakukan tersebut untuk membuktikan hipotesis penelitian.

\section{Hipotesis Penelitian}

Ho: Penggunaan Flipbook materi gerbang logika dengan berbantuan livewire tidak ada berpengaruh terhadap kemempuan berpikir logis.

Ha: Penggunaan Flipbook materi gerbang logika dengan berbantuan livewire berpengaruh terhadap kemempuan berpikir logis.

Dengan paradigma penelitian sesuai dengan berikut:

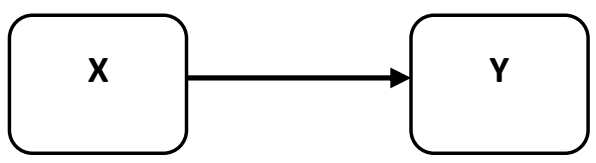

Keterangan :

$\mathrm{X}=$ variabel bebas yaitu penggunaan flipbook dengan bantuan livewire
$\mathrm{Y}$ = variebel terikat yaitu kemampuan berpikir logis

\section{Instrument dan Teknik Analisis Data}

Instrumen yang digunakan untuk mengukur kemampuan berpikir logis yaitu menggunakan tes tertulis jenis pilihan ganda. Kemudian dilanjutkan dengan wawancara tak terstruktur menanyakan bagian atau pokok permasalahan sesuai dengan topik penelitian.

Analisis instrument soal pilihan ganda meliputi validitas, reabilitas, daya pembeda dan tingkat kesukaran dengan bantuan program SPSS 16.0. Untuk analisis data validitas soal menggunakan Corralate Bivariate dengan analisis jika nilia signifikasnsi $<0,05$ butir soal dikatakan valid. Analisis reabilitas dengan membandingkan nilai cronbach's Alpha dengan kategori rentang $0,8-1,0$ sangat reliable; rentang 0,6 -0,7 reliabel; rentang 0,4 $-0,5$ cukup reliable; dan rentang 0,2-0 tidak reliable.

Tingkat kesukaran juga menggunakan program SPSS 16.0 dengan Anlyze Frequencies yang memunculkan nilai Mean kemudian ditafsirkan kedalam rentang kategori 0,00 - 0,20 soal sukar, 0,21 - 0,70 soal sedang dan 0,70 - 1,00 untuk kategori soal rendah. Kemudian untuk analisis daya pembeda menggunakan nilai pearson correlation pada uji validitas yang ditafsirkan dengan kategori sebagai berikut :

$$
\begin{aligned}
0,40-1,00 & =\text { Soal Baik } \\
0,30-0,39 & =\text { Soal Diterima } \\
0,20-0,29 & =\text { Soal perbaiki/Diubah } \\
0,00-0,19 & =\text { Soal Ditolak }
\end{aligned}
$$

Analisis data awal yaitu uji normalitas menggunakan KolmogrofSmirnov dengan software SPSS dengan 
hipotesis $\mathrm{H}_{0}$ : data tidak berditribusi normal jika < nilai signifikansi $0,05 . \mathrm{H}_{\mathrm{a}}$ : data berdistribusi normal jika > nilai signifikansi 0,05. Uji homogenitas melalui uji Levene yang pada umumunya. Dengan hipotesis homogenitas $\mathrm{H}_{0}$ : Varians tidak homogen jika $<$ nilai signifikansi $0,05 . \mathrm{H}_{\mathrm{a}}$ : varians homogeny jika > nilai signifikansi 0,05 .

Analisis data akhir untuk mengetahui pengaruh penggunaan Flipbook gerbang logika dengan menggunakan Livewire terhadap kemampuan berpikir logis mahasiswa teknik informatika yaitu regresi sederhana. Uji regresi mengunakan program SPSS 16.0 kemudian dianalisis dari hasil data yang didapatkan.

\section{HASIL DAN PEMBAHASAN}

Hasil analisis instrument butir soal tes yang dilakukan didapatkan validitas, realibilitas, tingkat kesukaran dan daya pembeda. Sesuai dengan tabel 2 untuk data validitas butir soal didapatkan 4 (empat) soal dengan nomor soal 5, 14, 16, dan 20 dengan nilai $\mathrm{p}$ Value Sig. $<0,05$ menunjukan butir soal tersebut tidak valid. Kemudian untuk butir soal yang valid yang memiliki $\mathrm{p}$ Value Sig. > 0,05 yaitu butir soal 1, 2, 3, 4, 6, 7, 8, $9,10,11,12,13,15,17,18,19,21,22,23$, 24, dan 25 .

Data tingkat kesukaran tabel 2 didapatkan dua soal mudah yaitu soal nomor 1 dan 16, dua soal sukar yaitu dengan nomor 5 dan 20, untuk soal sedang dengan nomor 2, $3,4,6,7,8,9,10,11,12,14,15,17,18,19$, $21,22,23,24$, dan 25. Daya pembeda dengan menggunakan dari data perhitungan pearson Correlation tiga soal ditolak yaitu 5, 14 dan 20 selebihnya soal dikatakan memiliki daya pembeda yang baik. Dari analisis tersebut soal yang bisa dipakai untuk digunakan untuk instrument pengambilan data 20 soal.
Tabel 2. Hasil Validitas, Tingkat Kesukaran dan Daya Pembeda

\begin{tabular}{|c|c|c|c|c|c|c|}
\hline \multirow{3}{*}{1} & \multicolumn{3}{|c|}{ Validitas } & \multicolumn{2}{|c|}{$\begin{array}{c}\text { Tingkat } \\
\text { Kesukaran }\end{array}$} & \multirow{2}{*}{$\begin{array}{l}\begin{array}{l}\text { Daya } \\
\text { beda }\end{array} \\
\text { Baik } \\
\end{array}$} \\
\hline & $\mathrm{PC}$ & 0.47 & & 87 & Mudah & \\
\hline & Sig. & 0.007 & Valid & & & \\
\hline \multirow{2}{*}{2} & $\mathrm{PC}$ & 0.49 & & \multirow{2}{*}{0.63} & \multirow{2}{*}{ Sedang } & Baik \\
\hline & Sig. & 0.005 & Valid & & & \\
\hline \multirow{2}{*}{3} & $\mathrm{PC}$ & 0.42 & & \multirow{2}{*}{0.57} & \multirow{2}{*}{ Sedang } & Baik \\
\hline & Sig. & 0.02 & Valid & & & \\
\hline \multirow{2}{*}{4} & $\mathrm{PC}$ & 0.50 & & \multirow{2}{*}{0.63} & \multirow{2}{*}{ Sedang } & Baik \\
\hline & Sig. & 0.004 & Valid & & & \\
\hline \multirow{2}{*}{5} & PC & -0.19 & & \multirow{2}{*}{0.13} & \multirow{2}{*}{ Sukar } & Ditolak \\
\hline & Sig. & 0.30 & Drop & & & \\
\hline \multirow{2}{*}{6} & $\mathrm{PC}$ & 0.54 & & \multirow{2}{*}{0.60} & \multirow{2}{*}{ Sedang } & Baik \\
\hline & Sig. & 0.002 & Valid & & & \\
\hline \multirow{2}{*}{7} & $\mathrm{PC}$ & 0.51 & & \multirow{2}{*}{0.37} & \multirow{2}{*}{ Sedang } & Baik \\
\hline & Sig. & 0.003 & Valid & & & \\
\hline \multirow{2}{*}{8} & PC & 0.69 & & \multirow{2}{*}{0.43} & \multirow{2}{*}{ Sedang } & Baik \\
\hline & Sig. & 0 & Valid & & & \\
\hline \multirow{2}{*}{9} & PC & 0.63 & & \multirow{2}{*}{0.33} & & Baik \\
\hline & Sig. & 0 & Valid & & & \\
\hline 10 & PC & 0.55 & & 47 & Sedano & Baik \\
\hline & Sig. & 0.002 & Valid & & Non & \\
\hline 11 & $\mathrm{PC}$ & 0.51 & & & & Baik \\
\hline & Sig. & 0.004 & Valid & & & \\
\hline 12 & PC & 0.43 & & 60 & $\mathrm{Se}$ & Baik \\
\hline & Sig. & 0.015 & Valid & & & \\
\hline 13 & PC & 0.46 & & 33 & Sedano & Baik \\
\hline & Sig. & 0.01 & Valid & & & \\
\hline 14 & PC & 0.21 & & 47 & $\mathrm{C}$ & Diubah \\
\hline & Sig. & 0.25 & Drop & & & \\
\hline 15 & PC & 0.47 & & 33 & Sed & Baik \\
\hline & Sig. & 0.008 & Valid & & Newaing & \\
\hline 16 & PC & 0.02 & & 77 & Mudah & Ditolak \\
\hline & Sig. & 0.88 & Drop & & & \\
\hline 17 & PC & 0.45 & & 17 & S & Baik \\
\hline & Sig. & 0.01 & Valid & & & \\
\hline 18 & PC & 0.45 & & 047 & Sedang & Baik \\
\hline & Sig. & 0.01 & Valid & & & \\
\hline 19 & $\mathrm{PC}$ & 0.69 & & 0.43 & Sedang & Baik \\
\hline
\end{tabular}




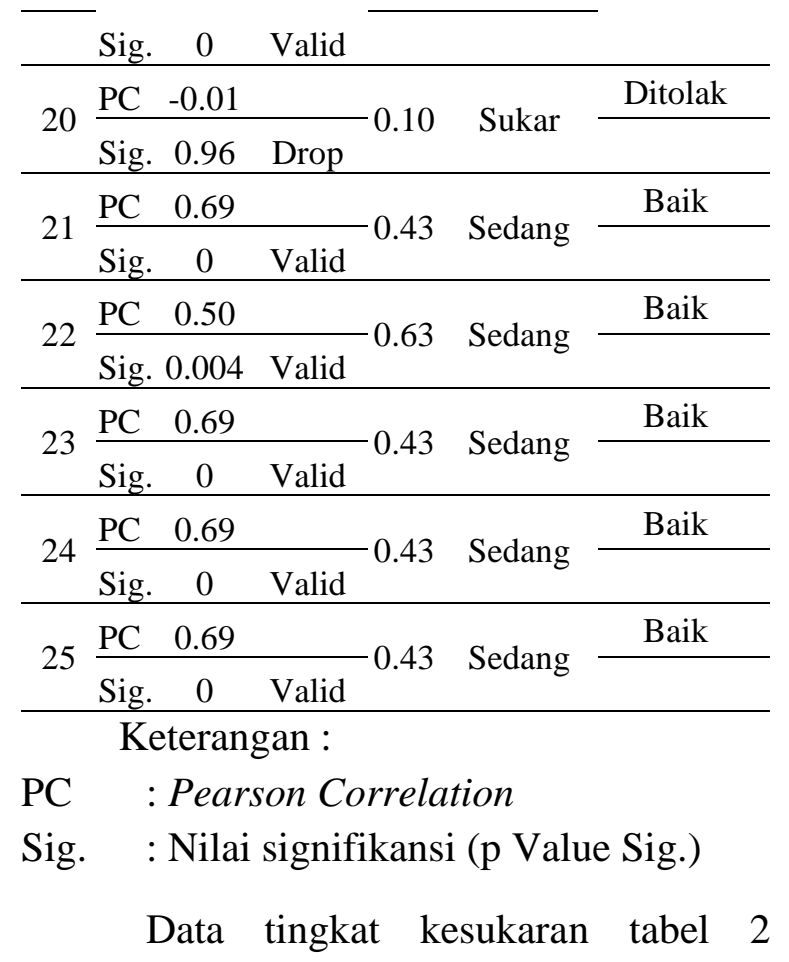
didapatkan dua soal mudah yaitu soal nomor 1 dan 16 , dua soal sukar yaitu dengan nomor 5 dan 20, untuk soal sedang dengan nomor 2 , $3,4,6,7,8,9,10,11,12,14,15,17,18,19$, $21,22,23,24$, dan 25. Daya pembeda dengan menggunakan dari data perhitungan pearson Correlation tiga soal ditolak yaitu 5, 14 dan 20 selebihnya soal dikatakan memiliki daya pembeda yang baik. Dari analisis tersebut soal yang bisa dipakai untuk digunakan untuk instrument pengambilan data 20 soal.

Data reliabilatas yang didapat dari perhitungan cronbach's Alpha yaitu 0.867 diantara rentang $0,8-1,00$ dalam kategori sangat tinggi. Sesuai dengan tabel 3 berikut ini :

Tabel 3. Reliability Statistics

\begin{tabular}{|c|c|}
\hline Cronbach's Alpha & $\mathrm{N}$ of Items \\
\hline 0.867 & 25 \\
\hline
\end{tabular}

normalitas dari data pretes dengan menggunakan program SPSS didapatkan hasil pada tabel 4 berikut :
Tabel 4. Hasil Uji Normalitas

\begin{tabular}{llllllll}
\hline & \multicolumn{3}{c}{$\begin{array}{c}\text { Kolmogorov- } \\
\text { Smirnov }\end{array}$} & \multicolumn{3}{c}{ Shapiro-Wilk } \\
\cline { 2 - 7 } & Statistic & df & Sig. & Statistic & df & Sig. \\
\hline Pretes & \multicolumn{1}{c}{.148} & 30 & .090 & .926 & 30 & .039 \\
\hline & Tabel & 4 & pada & hasil & stastistik
\end{tabular}

Kolmogrof -Semirnov diperoleh nilai $p$ value Sig. yaitu 0,09 menunjukan lebih dari taraf kesalahan 0,05 (Sig. > 0,05) maka seluruh varibel berdistribusi normal. Untuk uji homogenitas dengan program SPSS didapatkan hasil pada tabel 5 berikut :

Tabel 5. Uji Homogenitas

\begin{tabular}{ccccc}
\hline Levene Statistic & \multicolumn{1}{l}{ df1 } & \multicolumn{1}{c}{ df2 } & Sig. \\
\hline 1.996 & 7 & 18 & .112 \\
\hline Tabel & 5 & menunjukan & hasil
\end{tabular}

perhitungan uji Levene diperoleh $\mathrm{p}$ Value Sig. yaitu 0,112 lebih dari taraf kesalahan 0,05 (Sig.>0,05) maka disimpulkan bahwa varians dari data bersifat homogen. Berdasarkan hasil data normalitas dan homogenitas maka data bisa digunakan untuk penelitian.

Setelah dilakukan perlakuan atau treatmen pada sampel dengan dilakukan pengambilan data postes kemudian dianalisis regresi sederhana. Analisis pengaruh Flipbook gerbang logika menggunakan Livewire terhadap kemampuan berpikir logis diperoleh hasil tabel 6 berikut :

Tabel 6. ANOVA ${ }^{\mathrm{b}}$

\begin{tabular}{cccccc}
\hline Model & $\begin{array}{c}\text { Sum of } \\
\text { Squares }\end{array}$ & df & $\begin{array}{c}\text { Mean } \\
\text { Square }\end{array}$ & F & Sig. \\
\hline 1 Regression & 3526.061 & 1 & 3526.06 & 50.96 & $.000^{\mathrm{a}}$ \\
\hline Residual & 1937.405 & 28 & 69.193 & & \\
\hline Total & 5463.467 & 29 & & & \\
\hline
\end{tabular}

Tabel 6 menunjukan nilai $\mathrm{F}=50,96$ dengan $\mathrm{p}$ Value Sig. 0,000 <0,05 yang berarti hipotesis $\mathrm{H}_{\mathrm{o}}$ ditolak, dari data regresi sederhana tersebut penggunaan Flipbook gerbang logika menggunakan Livewire berpengaruh pada kemampuan berpikir logis mahasiswa teknik informatika. Sedangakan 
besarnya pengaruh dari variabel terikat dan variabel bebasnya dilihat dalam tabel 7 berikut:

Tabel 7. Model Summary

\begin{tabular}{|c|c|c|c|c|}
\hline Model & $\mathbf{R}$ & $\begin{array}{c}\mathbf{R} \\
\text { Square }\end{array}$ & $\begin{array}{c}\text { Adjusted R } \\
\text { Square } \\
\end{array}$ & $\begin{array}{l}\text { Std. Error of } \\
\text { the Estimate }\end{array}$ \\
\hline 1 & $.803^{\mathrm{a}}$ & .645 & .633 & 8.3182360 \\
\hline
\end{tabular}
pengaruh dilihat dari data nilai $R$ square $=$ 0,645 jika dipresentasekan 64,5\%. Artinya nilai 64,5 \% kemampuan berpikir logis dipengaruhi oleh penggunaan Flipbook materi gerbang logika bantuan Livewire. Dan $35.5 \%$ sisanya dipengaruhi oleh faktor lain. Kemudian untuk persamaan regresi sederhana diperoleh sesuai dengan tabel 8 berikut :

Tabel 8. Coefficients ${ }^{\mathrm{a}}$

\begin{tabular}{cccccc}
\hline \multicolumn{2}{c}{$\begin{array}{c}\text { Unstandardized } \\
\text { Coefficients }\end{array}$} & $\begin{array}{c}\text { Standardized } \\
\text { Coefficients }\end{array}$ & & \\
\cline { 1 - 4 } B & $\begin{array}{c}\text { Std. } \\
\text { Error }\end{array}$ & Beta & t & Sig. \\
\hline-81.776 & 18.503 & & -4.420 & .000 \\
\hline 1.809 & .253 & & .803 & 7.139 & .000 \\
\hline \multicolumn{4}{c}{ Pada tabel } & 8 & menunjukan hubungan
\end{tabular}

antara varibel terikat yaitu kemampuan berpikir logis terhadap varibel bebas penggunaan Flipbook materi gerbang logika bantuan Livewire. Maka persamaan regresi bisa di rumuskan sebagai berikut $\widehat{\boldsymbol{Y}}=$ $-\mathbf{8 1}, \mathbf{7 7 6}+\mathbf{1 8}, \mathbf{5 0 3} \boldsymbol{x}$. Persamaan tersebut memiliki arti setiap penambahan penggunaan Flipbook materi gerbang logika bantuan Livewire sebesar satu satuan maka bisa menambah kemampuan berpikir logis mahasiswa sebesar 18,503 dan membuktikan bahwa $\mathrm{H}_{\mathrm{a}}$ diterima dan $\mathrm{H}_{0}$ diterima. Jadi Flipbook materi gerbang logika bantuan Livewire memiliki pengaruh positif terhadap kemampuan berpikir logis mahasiswa.

Kurikulum pendidikan tinggi yang berbasis KKNI sekarang ini membutuhkan capaian pembelajaran dalam penyusununnya.
Dalam pencapaian pembelajaran ini harus melalui deskripsi, asessmen dan tanggujawap penuhan mandiri. Hal ini menunjukan dibutuhkanya untuk melakukan proses sehingga tercapai apa yang sudah direncanakan dalam pembelajaran.

Sebagai sarana untuk pencapaian pembelajaran salah satunya digunakan bahan ajar. Dari penggunaan Flipbook materi gerbang logika dengan bantuan Livewire menunjukan bahwa memliki pengaruh dalam kemampuan berpikir logis mahasiswa. Ditunjukan dari hasil analisis regresi sederhana dimana pada tabel $6 \mathrm{p}$ Value Sig. $0,000<0,05$ yang artinya hipotesis Ho ditolak. Penerapan flipbook memberikan dampak langsung kepada mahasiswa dalam tampilan. Mahasiswa menjadi tertarik dalam pembelajaran dan terlibat langsung dalam pembelajaran, karena dalam pembelajaran terdapat praktikum yang bisa dijadikan interaksi atau keterlibatan langsung mahasiswa dalam pembelajaran. Seperti pada penelitian Akmam dkk pembelajaran yang merujuk pada interaktif dan inspiratif memberikan kesempatan pada mahasiswa untuk berperan aktif dalam perkuliahan sehingga memunculkan ruang untuk pengembangan dalam prakarsa, kreativitas, dan kemandirian (Akmam, Amir, \& Asrizal, 2016).

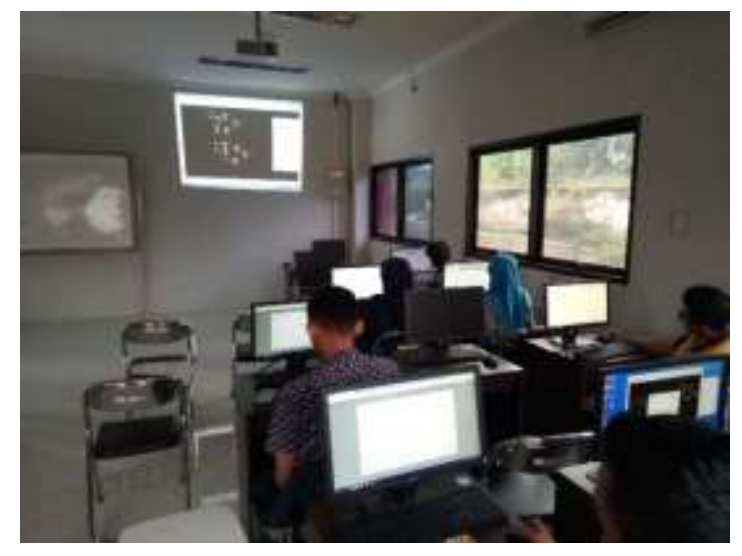

Gambar 1. Penggunaan flipbook berbantuan livewire 
Seperti pada gambar 1. Menujukan proses siswa ikut dalam interaksi perkuliahan. Dengan menggunakan program livewire siswa melakukan eksperimen dengan mengaplikasikan rangkaian gerbang logika dan menguji tabel kebenaranya secara langsung. Dari kegiatan tersebut mahasiswa bisa mendapatkan pengetahuan yang secara tidak sadar dari pembuktian yang dilakukan dirinya sendiri.

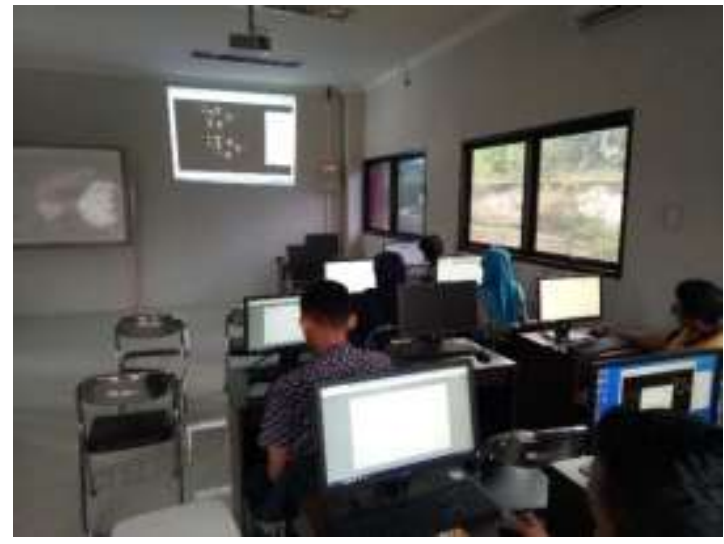

Gambar 1. Penggunaan flipbook berbantuan livewire

Pada gambar 2 mahasiswa juga diberi kesempatan dalam mengeksplorasi materi melalui praktikum dengan program livewire dan ini membuat mahasiswa mampu mengkonstruksi pengetahuan dalam berpikir logis. Karena kemampuan berpikir logis membutuhkan pemahaman yang lebih karena terkait dengan penggunaan persamaan gerbang logika. Konstruksi perilaku, pengetahuan dan keterampilan tambahan bisa melalui pembelajaran yang melibatkan, memiliki motivasi yang menginspirasi, dan menyenangkan yaitu melalui integrasi dengan ICT (Akmam., Harman, Asrizal., Dilla, \& Atika, 2014).

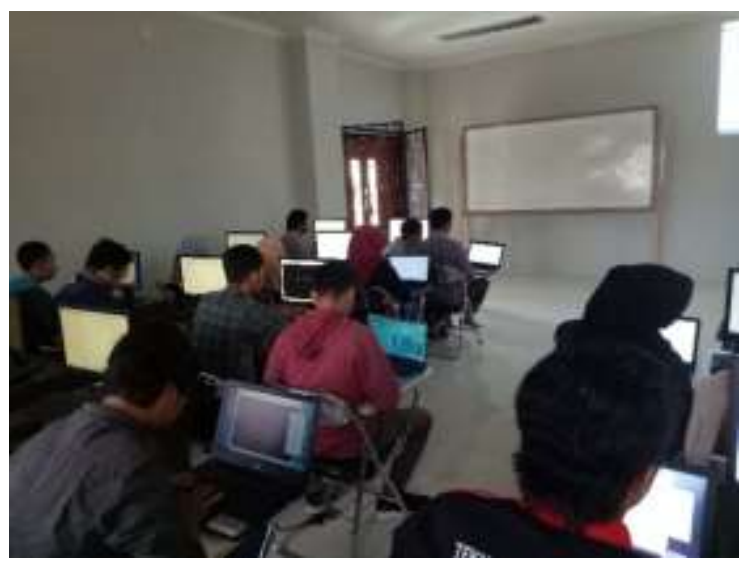

Gambar 2. Mahasiswa praktikum dengan livewire

Pengaruh yang ditunjukan dalam analisis di tabel 7 yang menujukan besarnya sampai $64,5 \%$ pengaruh penggunaan bahan ajar flipbook ini dalam pembentukan berpikir logis. Penggunaan yang secara mandiri dan integrasi dengan program laboratorium maya livewire membuat mahasiswa memiliki inisiatif untuk memecahakan masalah dalam memahami teori gerbang logika. Dan penggunaan flipbook ini bisa digunakan dimana saja karena berbentuk file yang bisa dipindah kedalam gadget/ ponsel pintar maupun komputer ataupun laptop. Stantchev dkk dalam penelitianya pembelajaran menggunakan sistem dan awan file (cloud file) menunjukan siswa lebih dalam menggunakan dan mudah dalam memanfaatkan dalam setiap pembelajaran (Stantchev, Colomo-Palacios, Soto-Acosta, \& Misra, 2014). Penelitian semua yang berbasis elektronik memiliki keunggulan dalam kemudahan mengakses, portabel, dan penyebaranya cepat, lebih ramah lingkungan karena tidak menggunakan kertas (Jarrott \& Eubanks Gambrel, 2011) 


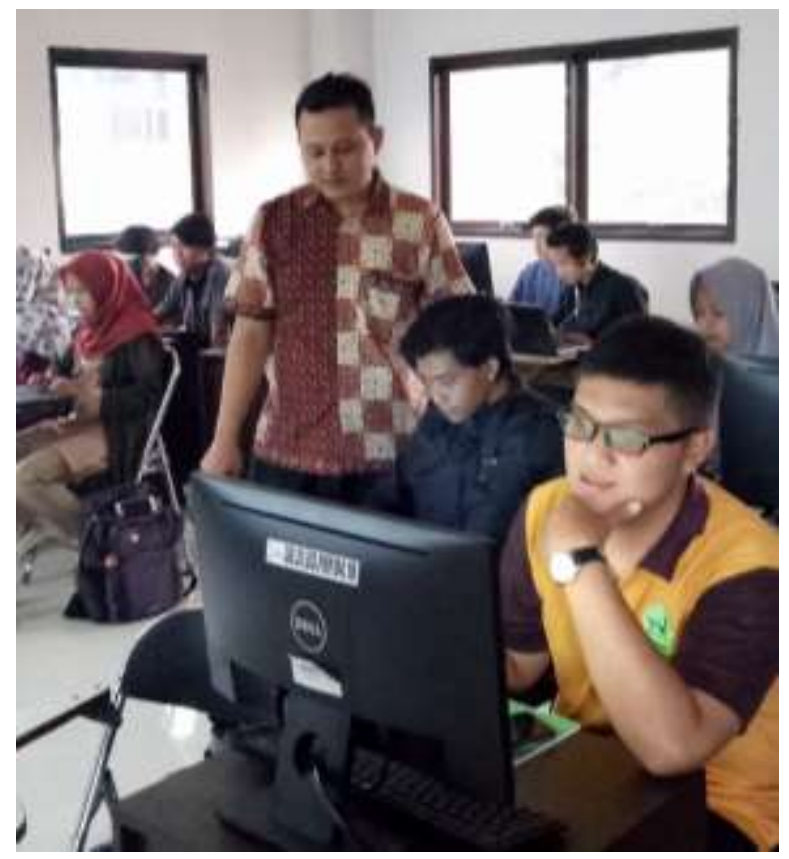

Gambar 3. Proses wawancara

Didukung dengan data hasil wawancara tidak struktur sesuai dengan gambar 3 sebagai berikut, "apa yang menjadi kesulitan dalam mempelajari gerbang logika?" mahasiswa menjawab "iya pak sulit, karena kita harus mempelajari operasi dengan bilangan yang baru, tidak seperti biasanya". Pertanyaan "apakah dengan mencoba kamu akan bisa?" jawaban " iya pak bisa, karena kita bisa tau secara langsung pak". Pertanyaan selanjutnya "apa yang membedakan materi gerbang logika dengan materi yang lain?" jawaban "berbeda pak, karena harus diulang terus biar bisa paham". Pertanyaan "apakah dengan bantuan flipbook dan livewire ini kamu bisa lebih mudah memahami?" jawaban " iya pak, karena dengan bantuan tersebut bisa tau alasanya".

Media yang digunakan flipbook dan livewire mengandalakan konsep visual untuk memahami materi. Dan dalam Dari wawancara tersebut secara sadar mahasiswa mengungkapkan untuk pemahaman yang lebih untuk mempelajarai materi gerbang logika dan dengan bantuan dari flipbook dan livewire bisa memahami lebih mudah.
Karena melalui pembelajaran dengan media visual memiliki keunggulan dalam memahami akan tetapi lemah dalam instruksi verbal ditunjukan dengan menjawab pertanyaan yang secara singkat (Gani, Ibrahim, \& Khaerudin, 2019). Dari analisis data pada tabel 8 juga menjelaskan bahwa flipbook dan livewire memiliki dampak positif terhadap kemampuan berpikir logis mahasiswa. Kemp \&Dayton dalam (Abidin $\&$ Purbawanto, 2015) juga menyatakan bahwa pengaruh positif media pembelajaran adalah :

- Dalam menyampaian lebih terarah dan baku

- Lebih menarik dalam proses pembelajaran

- Penerapanya menjadi interaktif karena mahasiswa ikut dalam berpatifipasi, ada umpan balik dan penguatan.

- Waktu lebih fleksibel karena media sudah memuat keseluruhan materi, sehingga bisa digunakan diluar pembelajaran

- Media bisa menyapaikan materi secara terorganisir dengan baik, spesifik dan jelas

- Belajar bisa dimana saja dan kapan saja

- Meningkatkan sikap positif mahasiswa terhadap apa yang dipelajari

- Pengajar hanya memberikan arahan tidak lagi melakukan penjelasan yang berulang-ulang. 


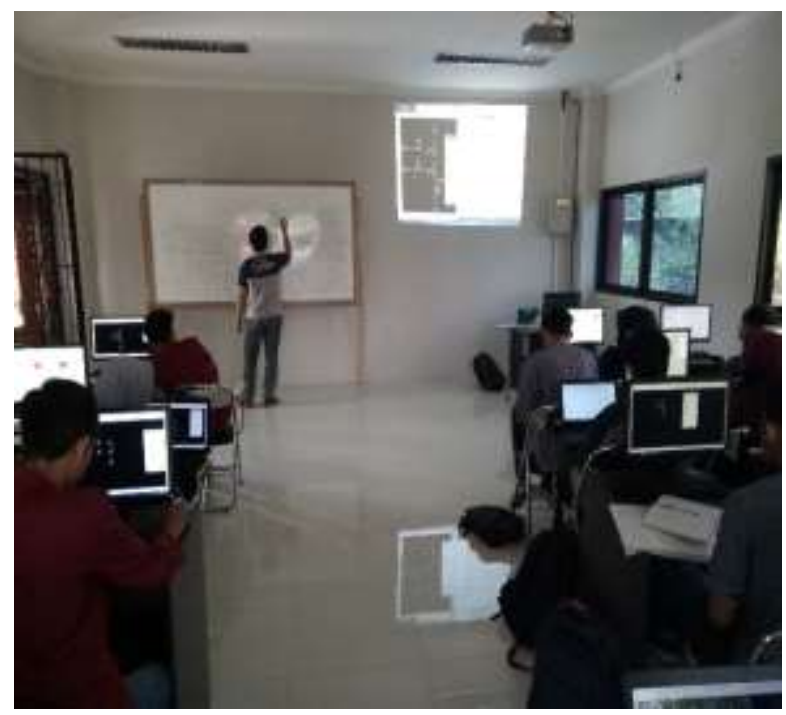

Gambar 4. Mahasiswa ikut berpartisipasi aktif dalam perkuliahan.

Pembentukan berpikir logis dalam materi gerbang logika sangat dibutuhkan, karena aljarbar yang ada pada gerbang logika memiliki keunikan yaitu menggunakan bilangan biner untuk penerapanya. Pada kenyaataanya kemempuan berpikir logis memiliki hubungan dengan intelegensi/ kecerdasan seseorang(Ab, Margono, \& Rahayu, 2019). Dibutuhkan juga penguatan untuk dalam memahami materi gerbang logika. Operasi yang berkaitan dengan matematika yang membutuhkan keterampilan berpikir logis akan lebih baik dilakukan penguatan (Bass \& Ball, 2018). Gambar 4 menunjukan penguatan yang bisa dilakukan dengan memunculkan umpan balik dari mahasiswa, dalam hal ini mahasiswa menjadi aktif dalam perkuliahan.

Pengembangan pengetahuan baru bisa melalui konstruksi wawasan dengan pendekatan baru yang dalam hal ini bisa digunakan sumber daya online yang berkembang saat ini(Wu et al., 2019). Berlaku juga dalam membuat konstruksi pengetahuan dalam materi gerbang logika memerlukan kemampuan berpikir logis yang mendalyang baru. Maharani dkk menyebutkan bahwa melalui masalah dalam pembelajaran membentuk pengetahuan alam untuk memunculkan kemampuan berpikir logis (Maharani, Darhim, Sabandar, \& Herman, 2019). Hal ini menunjukan bahwa pentingnya menyusun kemampuan berpikir logis melalui pembentukan/ konstruksi pengetahuan awal, ditambah lagi dengan materi gerbang logika yang menambahkan konsep aljabar baru dari bilangan bineram untuk menambah pengetahuan aljabar.

\section{PENUTUP \\ Simpulan}

Berdasarkan analisis data dan pembahasan dapat disimpulkan bahwa penggunaan flipbook berbantuan livewire berpengaruh dalam menumbuhkan kemampuan berpikir logis mahasiswa. Kemudian besar pengaruh penggunaannya sebesar $64,5 \%$ terhadap kemampuan berpikir kritis. Dengan berpikir logis melalui pembentukan/ konstruksi pengetahuan awal, ditambah lagi dengan materi gerbang logika yang menambahkan konsep aljabar baru dari bilangan biner.

\section{Saran}

Saran untuk penelitian selanjutnya yaitu melanjukan dengan pengembangan media inderaktif yang lain untuk peningkatan dalam perkuliahan di pendidikan tinggi

\section{DAFTAR PUSTAKA}

Ab, J. S., Margono, G., \& Rahayu, W. (2019). The Logical Thinking Ability: Mathematical Disposition and SelfRegulated Learning. Journal of Physics: Conference Series, 1155(1). https://doi.org/10.1088/17426596/1155/1/012092

Abidin, S., \& Purbawanto, S. (2015). Pemahaman Siswa Terhadap Pemanfaatan Media Pembelajaran Berbasis Livewere pada Mata Pelajaran Teknik Listrik Kelas X Jurusan Audio di SMK Negeri 4 Semarang. Edu Elektrika 
Journal, 4(1), 38-49.

Akmam., Harman, A., Asrizal., Dilla, O., \& Atika, U. A. (2014). Validitas Bahan Ajar Kontekstual Berbasis ICT dengan Mengintegrasikan Konsep MSTBK untuk Mencapai Kompetensi Fisika Siswa Kelas XI SMA. Jurnal Eksakta, 1(1), 11-19.

Akmam, Amir, H., \& Asrizal. (2016). Pengaruh Penggunaan Bahan Ajar Mengintegrasikan MSTBK Berbasis ICT Dalam Pembalajaran Fisika Di Kelas XI SMA. Prosiding SEMIRATA, 910-918.

Andini, S., Fitriana, L., \& Budiyono, B. (2018). Geometry in flipbook multimedia, a role of technology to improve mathematics learning quality: The case in madiun, east Java. Journal of Physics: Conference Series, 1008(1). https://doi.org/10.1088/17426596/1008/1/012077

Andriani, S., Nurlaelah, E., \& Yulianti, K. (2019). The effect of process oriented guided inquiry learning (POGIL) model toward students' logical thinking ability in mathematics. Journal of Physics: Conference Series, 1157(4). https://doi.org/10.1088/17426596/1157/4/042108

Bass, H., \& Ball, D. L. (2018). Review of Does Mathematical Study Develop Logical Thinking? Testing the Theory of Formal Discipline. International Journal of Research in Undergraduate Mathematics Education, 4(3), 442-447. https://doi.org/10.1007/s40753-0180076-7

Bird, L. (2010). Logical reasoning ability and student performance in general chemistry. Journal of Chemical Education, 87(5), 5541-5546. https://doi.org/10.1021/ed8001754

Diah, A., \& Rudy, K. (2017). The Development Of Interactive Electronic Book (BUDIN) Using Flip PDF
Professional To Train Higher Order Thinking Skills. Jurnal Inovasi Pendidikan Fisika ( JIPF) ISSN : 23024496 Jurnal Inovasi Pendidikan Fisika ( JIPF ) ISSN : 2302-4496, 06(03), 312318.

Divayana, D. G. H., Suyasa, P. W. A., Ariawan, I. P. W., Mahendra, I. W. E., \& Sugiharni, G. A. D. (2019). The Design of Digital Book Content for Assessment and Evaluation Courses by Adopting Superitem Concept Based on Kvisoft Flipbook Maker in era of Industry 4.0. Journal of Physics: Conference Series, 1165(1), 0-6. https://doi.org/10.1088/17426596/1165/1/012020

Dünser, A., Walker, L., Horner, H., \& Bentall, D. (2012). Creating Interactive Physics Education Books with Augmented Reality. In Proceedings of the 24th Australian Computer-Human Interaction Conference, 26(30), 107114. https://doi.org/10.1145/2414536.24145 54

Fadiana, M., Amin, S. M., Lukito, A., Wardhono, A., \& Aishah, S. (2019). Assessment of seventh grade students' capacity of logical thinking. Jurnal Pendidikan IPA Indonesia, 8(1), 75-80. https://doi.org/10.15294/jpii.v0i0.1164 4

Gani, A. A., Ibrahim, N., \& Khaerudin, K. (2019). Multimedia and Conventional Learning in Students with Visual and Auditory Learning styles: Experiments on Learning Outcomes. International Journal of Scientific Research and Management, 7(04), 978-982. https://doi.org/10.18535/ijsrm/v7i4.el0 2

Hanfstingl, B., Benke, G., \& Zhang, Y. (2019). Comparing variation theory with Piaget's theory of cognitive development: more similarities than 
differences? Educational Action Research.

https://doi.org/10.1080/09650792.2018. 1564687

Hidayatulloh, M. (2019). Developing Electrical Circuits Flipbook Using Flipbuilder. International Journal of Innovation Education and Research, $7(2)$, 124-134. https://doi.org/10.31686/ijier.vol7.iss2. 1331

Jarrott, S., \& Eubanks Gambrel, L. (2011). The Bottomless File Box: Electronic Portfolios for Learning and Evaluation Purposes. International Journal of EPortfolio, 1(1), 85-94.

Maharani, A., Darhim, Sabandar, J., \& Herman, T. (2019). PBL-Team Teaching: Supporting Vocational Students Logical Thinking and Creative Disposition. Journal of Physics: Conference Series, 1188(1). https://doi.org/10.1088/17426596/1188/1/012026

Nursuprianah, I., \& Fitriyah, R. A. (2012). Hubungan Pola Berpikir Logis dengan Hasil Belajar Matematika Siswa. EDUMA, 1(2), 14-24. https://doi.org/http://dx.doi.org/10.2423 5/eduma.v1i2.294

Philips, R. (2014). The Developer's Handbook of Interactive Multimedia. In The Developer's Handbook of Interactive Multimedia (1st Editio). https://doi.org/10.4324/9781315041889

Priwantoro, S. W., Fahmi, S., \& Astuti, D. (2018). Pengembangan E-Modul Berbasis Kvisoft Flipbook Maker Dipadukan Dengan Geogebra Sebagai Alternatif Media Pembelajaran Mata Kuliah Program Linier. Seminar Nasional Pendidikan Matematika, 744757.

Riyanti, H., Karyanto, P., \& Article, H. (2018). Biosaintifika. 10(3), 648-654. https://doi.org/https://doi.org/10.15294/ biosaintifika.v10i3.16612

Rockinson- Szapkiw, A. J., Courduff, J., Carter, K., \& Bennett, D. (2013). Electronic Versus Traditional Print Textbooks: A Comparison Study on the Influence of University Student's Learning. Computers \& Education, 63, 259-266.

https://doi.org/10.1016/j.compedu.2012 .11 .022

Stantchev, V., Colomo-Palacios, R., SotoAcosta, P., \& Misra, S. (2014). Learning management systems and cloud file hosting services: A study on students' acceptance. Computers in Human Behavior, 31, 612-619. https://doi.org/10.1016/j.chb.2013.07.0 02

Subekti, E. E. (2011). Menumbuh kembangkan Berpikir Logis dan Sikap Positif terhadap Matematika melalui Pendekatan Matematika Realistik. Majalah Ilmiah Pendidikan Dasar), 1(1), 1-11. https://doi.org/http://dx.doi.org/10.2687 7/malihpeddas.v1i1.62

Wibowo, E., \& Dkk. (2018). Pengembangan Bahan Ajar Menggunakan Aplikasi Kvisoft Flipbook Maker Materi Himpunan Pendidikan merupakan sarana untuk menuju kepada pertumbuhan dan perkembangan bangsa. Pendidikan juga merupakan investasi sumber daya manusia jangka panjang yang mempunyai. 1(2), 147156.

Wu, Y. H., Fan, H. H., Qian, R., Zeng, Y., Yao, Y., Lin, J., ... Qiao, S. Y. (2019). Curriculum design and practice of Genetics blended course under the principle of constructive alignment. $Y i$ Chuan = Hereditas, 41(5), 439-446. https://doi.org/10.16288/j.yczz.19-035 